\title{
PAPERS
}

\section{Effect of topical oesophageal acidification on human salivary and oesophageal alkali secretion}

\author{
C M Brown, C F Snowdon, B Slee, L N Sandle, W D W Rees
}

\begin{abstract}
Recent human studies suggest that oesophageal $\mathrm{HCO}_{3}{ }^{-}$secretion, in conjunction with salivary $\mathrm{HCO}_{3}{ }^{-}$secretion and secondary oesophageal peristalsis, is important for the protection of oesophageal mucosa from refluxed gastric contents. This study evaluated simultaneously the responsiveness of oesophageal and salivary $\mathrm{HCO}_{3}{ }^{-}$secretion to oesophageal acidification in eight healthy subjects. A $10 \mathrm{~cm}$ segment of oesophagus was perfused at a constant rate of $5 \mathrm{ml} / \mathrm{min}$ with a specially designed tube assembly. Saline was used initially, and then $10 \mathrm{mM}$ and $100 \mathrm{mM} \mathrm{HCl}$. The perfusates contained ${ }^{3} \mathrm{H}$-polyethylene glycol (PEG) as a concentration marker to determine volumes. Corrections were applied for a small degree of contamination by swallowed saliva and refluxed gastric alkali. Oesophageal perfusion with $10 \mathrm{mM}$ HCl did not cause symptoms (nausea and heartburn), but tripled the oesophageal $\mathrm{HCO}_{3}{ }^{-}$output from a baseline of $51 \mu \mathrm{mol} / 10 \mathrm{~cm} / 10 \mathrm{~min}(p=0.021)$, while doubling the rate of salivary $\mathrm{HCO}_{3}{ }^{-}$secretion from a median basal value of $140 \mu \mathrm{mol} / 10 \mathrm{~min}(p=0 \cdot 021)$. Oesophageal perfusion with $100 \mathrm{mM} \mathrm{HCl}$ was associated with symptoms of nausea and heartburn in all subjects. The median oesophageal $\mathrm{HCO}_{3}{ }^{-}$output increased 32 fold to $1659 \mu \mathrm{mol} / 10 \mathrm{~cm} / 10$ min (interquartile range 569 to 3373; $\mathbf{p}=0.036$ ), and salivary $\mathrm{HCO}_{3}{ }^{-}$secretion approximately tripled from basal values $(p=0.036)$. In conclusion, oesophageal acidification stimulates both salivary and oesophageal $\mathrm{HCO}_{3}{ }^{-}$secretion, responses which may be protective to the oesophageal epithelium.

(Gut 1995; 36: 649-653)
\end{abstract}

Keywords: oesophageal secretion, saliva, bicarbonate, acid.

The stomach of vertebrates and mammals secretes a highly corrosive mixture of acid and pepsin, which is a potential threat to the integrity of the upper gastrointestinal mucosa. Reflux of gastric contents into the lower oesophagus is associated with either transient relaxation of the lower oesophageal sphincter or prolonged absence of sphincter pressure. ${ }^{1}$ Oesophageal cells are susceptible to acid attack which results in decreased ionic transport, cell swelling and death, and a local inflammatory response. $^{2-4}$ Acid reflux initiates secondary peristaltic waves, ${ }^{56}$ which serve to sweep acid back into the stomach, thereby reducing its volume and the length of time it is in contact with oesophageal mucosa. The oesophageal juxtamucosal $\mathrm{pH}$ remains low, however, until neutralisation of acid is achieved by alkali from either swallowed saliva, ${ }^{7-9}$ or oesophageal secretion. ${ }^{10-12}$

The human stomach and duodenum respond to topical acid by an increased rate of epithelial $\mathrm{HCO}_{3}{ }^{-}$transport, ${ }^{13}{ }^{14}$ and such an 'autoregulatory mechanism' may be protective to gastroduodenal mucosa. Several groups have already reported increased salivary secretion in response to oesophageal acidification, which in some instances is associated with symptoms such as heartburn and nausea. ${ }^{781215}$ The present experiments were designed to examine the oesophageal and salivary alkali responses to oesophageal acidification.

\section{Methods}

Basal secretion of alkali from salivary glands and the normal human oesophagus was quantified using a previously described and validated perfusion technique. ${ }^{12}$ In brief, a $10 \mathrm{~cm}$ segment of oesophagus was perfused at its proximal end with saline containing a nonabsorbable marker ( ${ }^{3} \mathrm{H}$-polyethylene glycol (PEG), $12.5 \mu \mathrm{Ci} / \mathrm{l}$ ) at a rate of $5 \mathrm{ml} / \mathrm{min}$. Samples were continually aspirated from the distal end of the segment $(35 \mathrm{~cm}$ from the incisors) and the alkali concentration was determined by back titration. Salivary contamination was minimised by aspirating the buccal cavity continuously and requesting subjects not to swallow during experiments. Inadvertently swallowed saliva was recognised by the appearance of amylase in oesophageal aspirates and corrections were applied for swallowed aliquots of salivary $\mathrm{HCO}_{3}{ }^{-}$. The stomach was perfused with a second marker solution ( ${ }^{14} \mathrm{C}$-PEG $\left.12.5 \mu \mathrm{Ci} / 1,5 \mathrm{ml} / \mathrm{min}\right)$ and corrections were applied for any oesophageal contamination by refluxed gastric fluid, from the appearance of the gastric marker in oesophageal aspirates. 
TABLE I Baseline experimental data in eight subjects, before acid perfusion of the oesophagus

\begin{tabular}{|c|c|c|c|c|c|c|c|}
\hline \multicolumn{3}{|c|}{ Subject } & \multirow{2}{*}{$\begin{array}{l}\% \\
\text { marker } \\
\text { recovery }\end{array}$} & \multirow{2}{*}{$\begin{array}{l}\text { Salivary } \\
\mathrm{HCO}_{3}- \\
\text { contamination } \\
(\mu \text { mol/10 min) }\end{array}$} & \multirow{2}{*}{$\begin{array}{l}\text { Gastric reflux } \\
\text { contamination } \\
\text { ( } \mu \text { mol/10 min) }\end{array}$} & \multirow[b]{2}{*}{$\begin{array}{l}\text { Net oesophageal } \\
\mathrm{HCO}_{3}^{-} \text {secretion } \\
(\mu \mathrm{mol} / 10 \mathrm{~cm} / 10 \mathrm{~min})\end{array}$} & \multirow[b]{2}{*}{$\begin{array}{l}\text { Total salivary } \\
\mathrm{HCO}_{3}^{-} \text {secretion } \\
(\mu \mathrm{mol} / 10 \text { min })\end{array}$} \\
\hline No & Sex & $\begin{array}{l}\text { Periods of } \\
\text { analysis }\end{array}$ & & & & & \\
\hline $\begin{array}{l}1 \\
2 \\
3 \\
4 \\
5 \\
6 \\
7 \\
8\end{array}$ & $\begin{array}{l}M \\
F \\
M \\
F \\
F \\
F \\
M \\
F\end{array}$ & $\begin{array}{l}4 \\
3 \\
1 \\
4 \\
3 \\
4 \\
2 \\
2\end{array}$ & $\begin{array}{l}73 \cdot 0 \\
47 \cdot 2 \\
45 \cdot 5 \\
63 \cdot 3 \\
70 \cdot 7 \\
53 \cdot 6 \\
64 \cdot 0 \\
24 \cdot 1\end{array}$ & $\begin{array}{r}0 \cdot 1 \\
16 \cdot 8 \\
27 \cdot 3 \\
75 \cdot 7 \\
14 \cdot 3 \\
0 \cdot 7 \\
0 \cdot 9 \\
0 \cdot 3\end{array}$ & $\begin{array}{l}0 \cdot 0 \\
0 \cdot 1 \\
0 \cdot 1 \\
0 \cdot 0 \\
0 \cdot 0 \\
0 \cdot 0 \\
0 \cdot 1 \\
0 \cdot 1\end{array}$ & $\begin{array}{l}17 \cdot 5 \\
84 \cdot 5 \\
54 \cdot 2 \\
47 \cdot 9 \\
39 \cdot 4 \\
15 \cdot 7 \\
54 \cdot 5 \\
56 \cdot 6\end{array}$ & $\begin{array}{r}17 \cdot 9 \\
1079 \cdot 9 \\
101 \cdot 8 \\
178 \cdot 4 \\
478 \cdot 6 \\
62.9 \\
221.8 \\
27 \cdot 0\end{array}$ \\
\hline \multicolumn{3}{|c|}{ Median } & $58 \cdot 4$ & $7 \cdot 6$ & $0 \cdot 1$ & $51 \cdot 0$ & $140 \cdot 1$ \\
\hline
\end{tabular}

\section{SUBJECTS}

Experiments were performed in eight healthy subjects (three men and five women aged between 20 and 27 years) with no evidence of current or previous gastrointestinal disease. Subjects specifically denied dyspeptic symptoms such as heartburn or nausea, had no gastrointestinal investigations, and had not taken any medication for dyspeptic symptoms in the past. Informed written consent was obtained and the experimental procedures were approved by the Salford Health Authority Ethics Committee.

\section{EXPERIMENTAL DESIGN}

Salivary and oesophageal alkali secretions were measured during a 60 minute basal period by perfusing a $10 \mathrm{~cm}$ segment of oesophagus with saline containing ${ }^{3} \mathrm{H}-\mathrm{PEG}$. The perfusate was then changed to an identical solution containing $10 \mathrm{mM} \mathrm{HCl}$ and perfused at the same rate of $5 \mathrm{ml} / \mathrm{min}$. To minimise contamination by any residual saline from the original perfusate, the test segment was flushed with a $50 \mathrm{ml}$ bolus of the $10 \mathrm{mM} \mathrm{HCl}$ solution during the first five minutes of acid perfusion. Aspirates were discarded during this five minute period. Salivary, oesophageal, and gastric aspirates were then collected during a further 10 minute period of acid perfusion. Alkali secretion into the oesophageal segment was calculated from direct titrations of the acid perfused and oesophageal aspirate. After a 30 minute 'washout period' when the acid perfusate was replaced by the saline perfusate, the same procedure was repeated using $100 \mathrm{mM} \mathrm{HCl}$ in six of the eight subjects.

Total oesophageal $\mathrm{HCO}_{3}{ }^{-}$content during the 10 minutes of acid perfusion could then be calculated from the oesophageal volume (determined by marker dilution) and reduction in titratable acidity of the acid perfusate caused by oesophageal alkali. In order to derive oesophageal $\mathrm{HCO}_{3}{ }^{-}$secretion, corrections were applied for swallowed saliva and refluxed gastric content as previously described. ${ }^{12}$

\section{ASSUMPTIONS AND VALIDATION}

(1) During acidification, amylase was denatured and enzymatic activity could not be detected within the oesophageal aspirates. It was therefore assumed that the proportion of saliva swallowed into the test segment remained constant during the entire experiment.

(2) In order to assess the efficiency of acid flushing in reducing residual saline within the test segment, experiments were conducted to measure the residual volume in four subjects. After a basal period of perfusion with labelled saline, the perfusate was changed to unlabelled saline for 15 minutes. During the initial five minutes of this 15 minute period, the segment was flushed with a $50 \mathrm{ml}$ bolus of unlabelled saline. From measurements of the concentration of ${ }^{3} \mathrm{H}-\mathrm{PEG}$ found in the final 10 minutes of saline perfusion, the residual volume of the initial perfusate could be calculated and it's potential impact on oesophageal $\mathrm{HCO}_{3}{ }^{-}$ output determined.

\section{STATISTICS}

The results are expressed as medians and interquartile ranges (Q1 to $Q 3)$. The significance of change in paired data was assessed using the Wilcoxon signed rank test, and $\mathrm{p}$ values of less than 0.05 were assumed to be significant. NS denotes non-significant changes.

TABLE II Oesophageal volume increased in only three of six subjects (3, 4, and 5) during perfusion with $100 \mathrm{mM} \mathrm{HCl}$. In these subjects the maximum possible contribution of swallowed saliva to measured oesophageal alkali content is estimated from the increase in oesophageal volume multiplied by the salivary alkali concentration. Since the oesophageal volume did not increase in subjects 2, 6, and 8, the possible increase in swallowed salivary alkali was not calculated and has been marked by ${ }^{\star}$ in the table

\begin{tabular}{|c|c|c|c|c|c|c|c|}
\hline \multirow{2}{*}{$\begin{array}{l}\text { Subject } \\
\text { no }\end{array}$} & \multicolumn{2}{|c|}{$\begin{array}{l}\text { Oesophageal volume } \\
\text { (mL/10 min) }\end{array}$} & \multicolumn{2}{|c|}{$\begin{array}{l}\text { Oesophageal alkali } \\
\text { concentration }(\mathrm{mM})\end{array}$} & \multirow{2}{*}{$\begin{array}{l}\text { Salivary alkali } \\
\text { concentration } \\
\text { during acid } \\
\text { perfusion } \\
(m M)\end{array}$} & \multirow{2}{*}{$\begin{array}{l}\text { Increased } \\
\text { oesophageal } \\
\mathrm{HCO}_{3}^{-} \text {with } \\
100 \mathrm{mM} \mathrm{HCl} \mathrm{HCl} \text { ( } 10 \mathrm{~mol} 10 \mathrm{~min})\end{array}$} & \multirow{2}{*}{$\begin{array}{l}\text { Possible } \\
\text { contribution } \\
\text { from } \uparrow \text { salivary } \\
\text { swallowing } \\
(\mu \mathrm{mol} 10 \mathrm{~min})\end{array}$} \\
\hline & Basal & Acid & Basal & Acid & & & \\
\hline $\begin{array}{l}2 \\
3 \\
4 \\
5 \\
6 \\
8 \\
8\end{array}$ & $\begin{array}{l}61 \cdot 2 \\
56 \cdot 9 \\
57 \cdot 8 \\
52 \cdot 6 \\
52 \cdot 3 \\
62 \cdot 7\end{array}$ & $\begin{array}{l}56 \cdot 0 \\
70.9 \\
65.4 \\
57.4 \\
53.7 \\
55.3\end{array}$ & $\begin{array}{l}0.36 \\
1.41 \\
2.13 \\
1.02 \\
0.30 \\
0.95\end{array}$ & $\begin{array}{l}22 \cdot 88 \\
49 \cdot 14 \\
36 \cdot 46 \\
16 \cdot 01 \\
10 \cdot 42 \\
62 \cdot 02\end{array}$ & $\begin{array}{r}22 \cdot 18 \\
6 \cdot 76 \\
11 \cdot 82 \\
14 \cdot 46 \\
9 \cdot 05 \\
7 \cdot 22\end{array}$ & $\begin{array}{r}1136 \\
3303 \\
2049 \\
533 \\
542 \\
3361\end{array}$ & $\begin{array}{r}\star \\
95 \\
90 \\
69 \\
\star \\
\star\end{array}$ \\
\hline
\end{tabular}




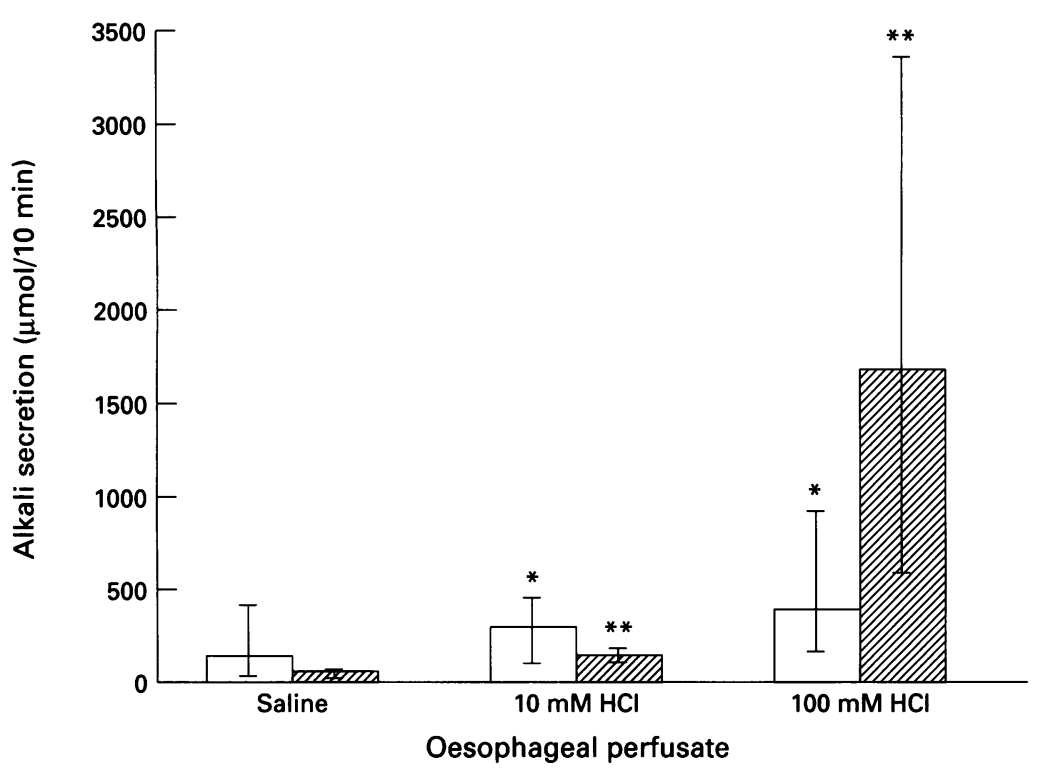

Figure 1: Salivary (open bars) and oesophageal (hatched bars) alkali outputs in response to oesophageal acidification. Medians and interquartile ranges are shown with significant changes from baseline indicated $\left(^{\star}\right.$ and $\left.{ }^{\star \star}, p \leqslant 0 \cdot 036\right)$.

\section{Results}

BASELINE

Basal experimental data on the eight subjects undergoing acid perfusion are outlined in Table I and net oesophageal alkali output includes correction for swallowed saliva and gastric reflux.

\section{DURING ACID PERFUSION}

\section{Validation data}

Calculation of swallowed saliva during acid perfusion. Further support for the validity of the assumption that the proportion of swallowed saliva remains unchanged during these experiments, was obtained from the calculated oesophageal volumes. If excess (unrecognised) saliva was swallowed during acid perfusion periods, an increase in the calculated

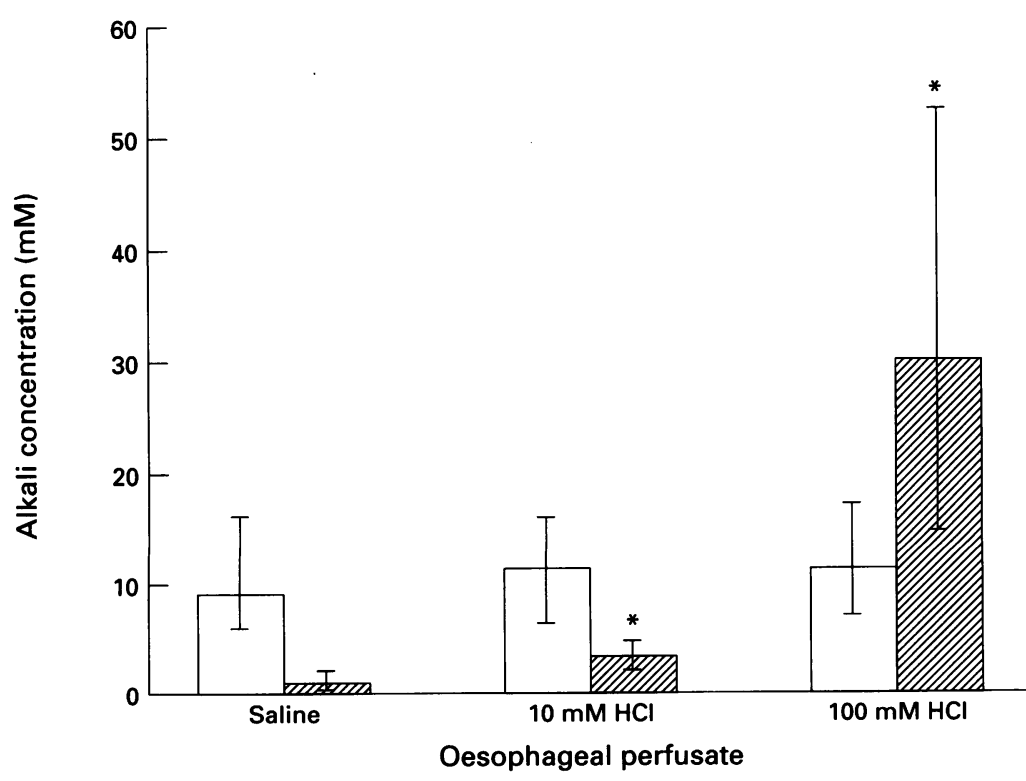

Figure 2: Salivary (open bars) and oesophageal (hatched bars) alkali concentrations at baseline (saline perfusion), and in response to oesophageal perfusion with $10 \mathrm{mM}$ and $100 \mathrm{mM} \mathrm{HCl}$. Medians and interquartile ranges are shown with significant changes from basal values indicated $\left(^{\star}\right.$, where $\left.p \leqslant 0.036\right)$. oesophageal volume would be expected. No volume increase was observed in subjects 2,6 , and 8 , and it is unlikely that the quantity of swallowed saliva changed between basal and acid perfusion periods in these. Subjects 3, 4, and 5, did exhibit a slight increase in oesophageal volume during $100 \mathrm{mM} \mathrm{HCl}$ perfusion, which could be explained either by an increase in undetected swallowed saliva or enhanced oesophageal secretion (Table II).

Dilutional error. Validation 'flushing' experiments in four subjects showed a median residual volume of $2.5 \mathrm{ml}$ (range 0.7 to 5.0 ) which could cause a $5 \%$ dilution of acid infused into the oesophagus over 10 minutes. Net oesophageal alkali output would therefore be overcalculated by approximately $5 \%$ but correction for this possibility did not alter the overall significance of the acidification response (Table III).

Acidification response. Median net oesophageal alkali output trebled from a basal median of $51 \mu \mathrm{mol} / 10 \mathrm{~cm} / 10 \mathrm{~min}$ (Q1 to Q3=23 to 56) to $140 \mu \mathrm{mol} / 10 \mathrm{~cm} / 10 \mathrm{~min}$ during perfusion with $10 \mathrm{mM} \mathrm{HCl}$ (Q1 to $\mathrm{Q} 3=91$ to $174, \mathrm{p}=0.021$ ). With $100 \mathrm{mM} \mathrm{HCl}$, oesophageal $\mathrm{HCO}_{3}{ }^{-}$secretion showed a 32 fold increase from basal levels to $1659 \mu \mathrm{mol} / 10$ $\mathrm{cm} / 10 \mathrm{~min}(\mathrm{Q} 1$ to $\mathrm{Q} 3=569$ to $3373, \mathrm{p}=0.036$; Table III and Fig 1). The proportionate increase in oesophageal $\mathrm{HCO}_{3}{ }^{-}$output with $100 \mathrm{mM} \mathrm{HCl}$, compared with basal, was much greater than the salivary response. Correction for residual saline in the oesophagus did not significantly influence these findings (Table III). The increased oesophageal alkali output was due to a threefold increase in oesophageal $\mathrm{HCO}_{3}{ }^{-}$concentrations with $10 \mathrm{mM} \mathrm{HCl}$ $(p=0.021)$, and a 30 fold increase in oesophageal $\mathrm{HCO}_{3}{ }^{-}$concentrations with $100 \mathrm{mM} \mathrm{HCl}(\mathrm{p}=0.036$; Fig 2). Oesophageal volumes did not significantly change from basal values during acid perfusion periods (Fig 3).

Salivary $\mathrm{HCO}_{3}{ }^{-}$secretion doubled from a median basal level of $140 \mu \mathrm{mol} / 10 \mathrm{~min}$ (Q1 to Q3 $=36$ to 414 ), to $291 \mu \mathrm{mol} / 10 \mathrm{~min}$ (Q1 to $\mathrm{Q} 3=86$ to 450 ) during oesophageal perfusion with $10 \mathrm{mM} \mathrm{HCl}(\mathrm{p}=0.021)$, and nearly tripled to $373 \mu \mathrm{mol} / 10 \mathrm{~min}(\mathrm{Q} 1$ to $\mathrm{Q} 3=150$ to 907) during oesophageal perfusion with $100 \mathrm{mM} \mathrm{HCl}(\mathrm{p}=0.036$; Fig 1$)$. The increase in salivary $\mathrm{HCO}_{3}{ }^{-}$output occurred because of a $23 \%$ increase in median salivary volume during oesophageal perfusion with $10 \mathrm{mM}$ $\mathrm{HCl}$, and a $100 \%$ increase during oesophageal perfusion with $100 \mathrm{mM} \mathrm{HCl}$ (Fig 3). Salivary alkali concentrations did not significantly change during acidification (Fig 2).

Symptoms of nausea and heartburn were absent during perfusion with $10 \mathrm{mM} \mathrm{HCl}$, but were present in all subjects during perfusion with $100 \mathrm{mM} \mathrm{HCl}$.

\section{Discussion}

The present perfusion studies were designed to measure both salivary and oesophageal $\mathrm{HCO}_{3}{ }^{-}$secretion, and the response to oesophageal acidification. They represent the first attempt to explore possible 'acid 


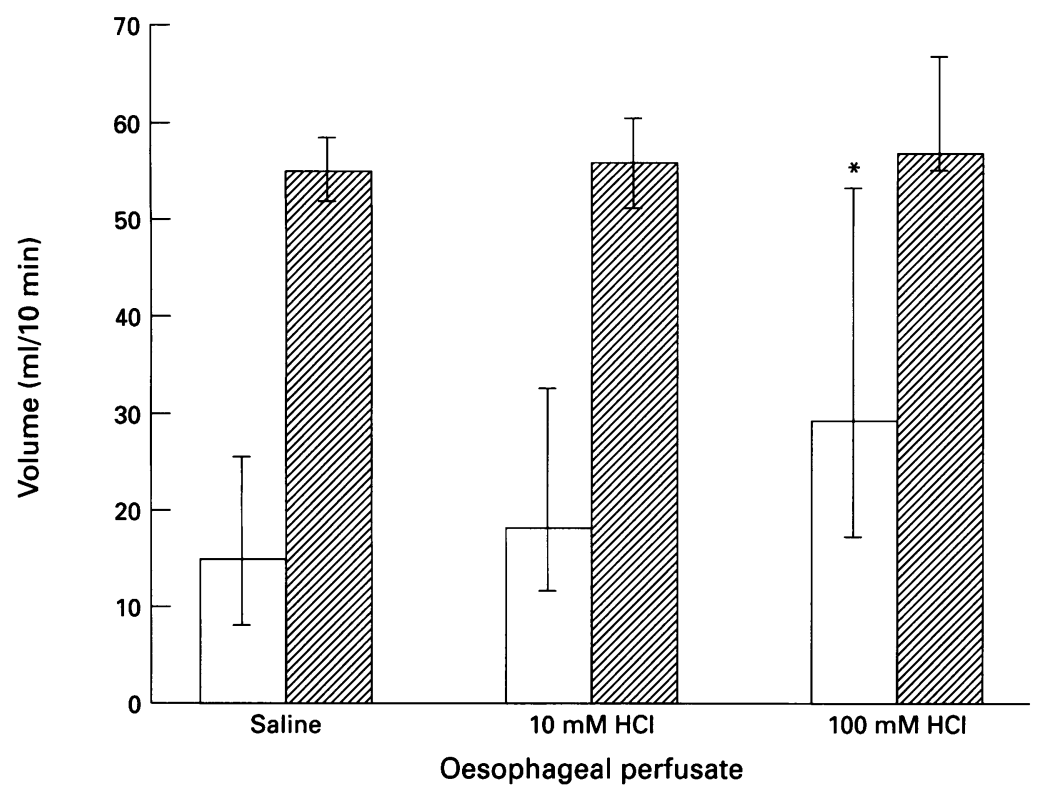

Figure 3: Salivary (open bars) and oesophageal (hatched bars) volumes at baseline (saline perfusion), and in response to oesophageal perfusion with $10 \mathrm{mM}$ and $100 \mathrm{mM} \mathrm{HCl}$. Medians and interquartile ranges are shown with significant changes from baseline indicated $\left({ }^{\star}\right.$, where $\left.p=0.036\right)$

autoregulation' of human oesophageal alkali secretion.

Salivary $\mathrm{HCO}_{3}{ }^{-}$secretion doubled in response to oesophageal perfusion with $10 \mathrm{mM}$ $\mathrm{HCl}$, in the absence of perceived symptoms such as nausea and heartburn. When $100 \mathrm{mM}$ $\mathrm{HCl}$ were infused into the oesophagus, all subjects perceived symptoms and the rate of salivary alkali secretion approximately tripled. This response was similar to previous experimental results, where $\mathrm{HCO}_{3}{ }^{-}$concentrations were determined from measurements of $\mathrm{pH}$ and $\mathrm{pCO}_{2} \cdot{ }^{12}$ There are conflicting data on the importance of symptom perception in mediating the salivary response to oesophageal acid, but such discrepancies can be reconciled if the degree of oesophageal exposure to acid is taken into consideration. It seems likely that the oesophageal acid threshold required to increase salivary secretion, is below that required for the generation of symptoms in each subject. Activated chemoreceptors in the oesophagus may stimulate salivary glands via neural reflex arcs, before the cerebral cortex is stimulated. Helm et al found that salivary secretion increased only in subjects who

TABLE III Net oesophageal alkali output in eight subjects, when the oesophagus is perfused with saline, $10 \mathrm{mM} \mathrm{HCl}$, or $100 \mathrm{mM} \mathrm{HCl}$. The data are presented with and without correction for dilutional error. Subjects 1 and 7 did not proceed to the stage of oesophageal perfusion with $100 \mathrm{mM} \mathrm{HCl}$, and the missing data are shown by ${ }^{\star}$ in the table

\begin{tabular}{|c|c|c|c|c|c|}
\hline \multirow[b]{3}{*}{ Subject } & \multicolumn{5}{|c|}{ Net oesophageal alkali secretion $(\mu \mathrm{mol} / 10 \mathrm{~cm} / 10 \mathrm{~min})$} \\
\hline & \multirow[b]{2}{*}{ Saline } & \multicolumn{2}{|l|}{$10 \mathrm{mM} \mathrm{HCl}$} & \multicolumn{2}{|l|}{$100 \mathrm{mM} \mathrm{HCl}$} \\
\hline & & Uncorrected & Corrected & Uncorrected & Corrected \\
\hline $\begin{array}{l}1 \\
2 \\
3 \\
4 \\
5 \\
6 \\
7 \\
8\end{array}$ & $\begin{array}{l}17 \cdot 9 \\
84 \cdot 5 \\
54 \cdot 2 \\
47 \cdot 9 \\
39 \cdot 4 \\
15 \cdot 7 \\
54 \cdot 5 \\
56 \cdot 6\end{array}$ & $\begin{array}{r}128 \cdot 1 \\
177 \cdot 0 \\
165 \cdot 0 \\
116 \cdot 3 \\
0 \cdot 0 \\
82 \cdot 4 \\
217 \cdot 4 \\
151 \cdot 1\end{array}$ & $\begin{array}{r}121 \cdot 7 \\
166 \cdot 0 \\
137 \cdot 1 \\
101 \cdot 8 \\
0 \cdot 0 \\
78 \cdot 2 \\
206 \cdot 4 \\
143 \cdot 3\end{array}$ & $\begin{array}{c}\star \\
1220 \cdot 9 \\
3357 \cdot 0 \\
2097 \cdot 1 \\
573 \cdot 3 \\
557 \cdot 7 \\
\star \\
3417 \cdot 9\end{array}$ & $\begin{array}{c}\star \\
1156 \cdot 7 \\
3182.8 \\
1977 \cdot 8 \\
527 \cdot 3 \\
529.7 \\
\star \\
3246.5\end{array}$ \\
\hline $\begin{array}{l}\text { Median } \\
\text { p Value }\end{array}$ & $51 \cdot 0$ & $\begin{array}{c}139.6 \\
0.021\end{array}$ & $\begin{array}{c}129.4 \\
0.021\end{array}$ & $\begin{array}{c}1659.0 \\
0.036\end{array}$ & $\begin{array}{c}1567.5 \\
0.036\end{array}$ \\
\hline
\end{tabular}

developed symptoms as a consequence of oesophageal acid perfusion. ${ }^{8}$ They suggested that symptoms were important in mediating this response, the so called 'oesophago-salivary reflex'. Previous studies by Sonnenberg had, however, shown that oesophageal acidification could enhance salivary flow in the absence of symptoms. ${ }^{15}$ In these experiments the human oesophagus was perfused with $10 \mathrm{mM} \mathrm{HCl}$ at a low rate $(16.7 \mathrm{ml} / \mathrm{h})$ and salivary secretion increased in asymptomatic subjects after an hour of acid perfusion. In the present studies, a higher rate of perfusion with $10 \mathrm{mM} \mathrm{HCl}$ ( $5 \mathrm{ml} / \mathrm{min}$ ) increased salivary $\mathrm{HCO}_{3}{ }^{-}$output within 15 minutes in the absence of symptoms. In our own previously reported studies, oesophageal perfusion with $100 \mathrm{mM} \mathrm{HCl}$ at a rate of $5 \mathrm{ml} / \mathrm{min}$ for five minutes, produced no symptoms or change in salivary secretion, but when perfusion was continued for 30 minutes, 10 of 12 subjects noticed symptoms and exhibited an increased salivary alkali output. ${ }^{12}$ Interestingly, the two asymptomatic subjects had a very high basal rate of salivary $\mathrm{HCO}_{3}{ }^{-}$ secretion. In the present studies, all subjects experienced symptoms between five and 10 minutes after the beginning of acid perfusion.

Median oesophageal $\mathrm{HCO}_{3}{ }^{-}$secretion nearly tripled in response to perfusion with $10 \mathrm{mM} \mathrm{HCl}$; a response which, although significant, was of a lesser magnitude than the increase in salivary alkali secretion. When the oesophagus was perfused with $100 \mathrm{mM} \mathrm{HCl}$, there was a very large rise in local oesophageal alkali output (a 32 fold increase), which far exceeded the salivary response. These effects are almost certainly due to local stimulation by $\mathrm{H}^{+}$ions rather than a volume effect, since the perfusion rates were identical for basal and acid perfusion periods, and there were no significant changes in oesophageal volume (Fig 2). This study shows for the first time that the human oesophagus is capable of responding to an acid load by significantly increasing its output of alkali. Such an 'autoregulatory' response may be important in mucosal defence, and assumes relatively greater significance in the presence of prolonged oesophageal exposure to acid, or in the absence of swallowed saliva during the nocturnal period. Similar protective responses have previously been shown in the human stomach ${ }^{13}$ and duodenum. ${ }^{14}$

It was not possible in these studies to examine an isolated segment of oesophagus, since in pilot studies subjects were intolerant of attempts to isolate and perfuse a segment between two occluding balloons. We were also unable to obtain $100 \%$ recovery of the infused marker, and therefore the methodology is quite complex. The accuracy of measurements of oesophageal volume, contamination by swallowed saliva and refluxed gastric fluid, and calculation of alkali content of recovered samples, have all been previously validated. ${ }^{12}$

Two further problems, which could potentially confound the results, were encountered with these studies. Firstly, amylase could not be measured in the acidic oesophageal aspirates, presumably due to inactivation of its enzymatic activity. The proportion of saliva which 
was swallowed was therefore measured for each subject during basal periods, and assumed to remain constant during the course of each experiment. Supporting evidence for the validity of this assumption came from previous experiments when a cholinergic stimulus increased median salivary secretion by $35 \%$, but the proportion of swallowed saliva did not change significantly, with a median of $6 \%$ during basal periods and $1 \cdot 2 \%$ during cholinergic stimulation. Furthermore, if this assumption were incorrect, any unrecognised swallowed saliva would increase the oesophageal volume, and such an increase was observed in only three of six subjects during perfusion with $100 \mathrm{mM} \mathrm{HCl}$. Even if all the increase in oesophageal volume were assumed to be due to swallowed saliva, its contribution to the oesophageal alkali content would be inadequate to explain the significant increase observed after acidification (Table II). This implies that oesophageal, rather than undetected salivary $\mathrm{HCO}_{3}{ }^{-}$was responsible for the oesophageal $\mathrm{HCO}_{3}{ }^{-}$response to infused acid.

The second potential confounding problem in these experiments, is whether any residual saline remained in the oesophageal test segment after the flushing procedure, thereby leading to simple dilution of infused acid, and an overestimation of oesophageal alkali content. Validation experiments in four subjects calculated that this could lead to a $5 \%$ over calculation of oesophageal alkali secretion, which was insufficient to influence the significance of values (Table III).

In summary, while these experiments lack technical perfection, the validation data provide support for the accuracy of both basal and acid stimulated oesophageal alkali output. These studies show that salivary $\mathrm{HCO}_{3}{ }^{-}$secretion is enhanced by acid perfusion of the oesophagus, and that this may occur independent of symptoms. They show, for the first time, that human oesophageal $\mathrm{HCO}_{3}{ }^{-}$ secretion is responsive to topical acid, which implies a protective autoregulatory mechanism. Both secretory responses to oesophageal acid occur in dose-dependent manner, and may well be relevant to the protection of the oesophageal mucosa against acid mediated injury.

Dr C M Brown was a Wellcome Trust Clinical Research Fellow. The authors wish to thank the Department of Medical Fellow. The authors wish to thank the Department of Medical Illustration at Hope Hospital for producing the figures. Some of these results were presented at a meeting of the British Society
of Gastroenterology in Manchester, March 1993; and of Gastroenterology in Manchester, March 1993; a
published in abstract form (Gut 1993; 34 (suppl 1): W38).

1 Dent J, Holloway RH, Toouli J, Dodds WJ. Mechanisms of lower oesophageal sphincter incompetence in patients with symptomatic gastro-oesophageal reflux disease. Gut 1988; 29: 1020-8.

2 Orlando RC, Bryson JC, Powell DW. Mechanisms of $\mathrm{H}^{+}$ injury in rabbit esophageal epithelium. Am $\mathcal{F}$ Physiol 1984 246: G718-24.

3 Tobey NA, Orlando RC. Mechanisms of acid injury to rabbit esophageal epithelium. Role of basolateral cell membrane acidification. Gastroenterology 1991; 101: 1220-8.

4 Tobey NA, Reddy SP, Keku TO, Cragoe Jr EJ, Orlando RC. Mechanisms of $\mathrm{HCl}$-induced lowering of intracellular pH in rabbit esophageal cells. Gastroenterology 1993; 105: $1035-44$.

5 Thompson DG, Andreollo NA, McIntyre AS, Earlam RJ Studies of the oesophageal clearance responses to intraluminal acid. Gut 1988; 29: 881-5.

6 Williams D, Thompson DG, Heggie L, Bancewicz J Responses of the human esophagus to experimental intraluminal distension. $A m$ f Physiol 1993; 265: G196-203.

7 Helm JF, Dodds WJ, Reidel DR, Teeter BC, Hogan WJ, Arndorfer RC. Determinants of esophageal acid clearance in normal subjects. Gastroenterology 1983; 85: 607-12.

8 Helm JF, Dodds WJ, Hogan WJ. Salivary responses to esophageal acid in normal subjects and patients with esophageal acid in normal subjects and patients

9 Shaker R, Kahrilas PJ, Dodds WJ, Hogan WJ. Oesophageal clearance of small amounts of equal or less than one millilitre of acid. Gut 1992; 33: 7-10.

10 Hamilton BH, Orlando RC. In vivo alkaline secretion by mammalian esophagus. Gastroenterology 1989; 97: 640-8

11 Meyers RL Orlando RC. In vivo alkaline secretion by human esophagus. Gastroenterology 1992; 103: 1174-8.

12 Brown CM, Snowdon CF, Slee B, Sandle LN, Rees WDW. Measurement of bicarbonate output from the intact human oesophagus. Gut 1993; 34: 872-80.

13 human oesophagus. Gut 1993; 34: 872-80. $\mathrm{pH}$ on the output of bicarbonate and $\mathrm{PgE}_{2}$ by the normal $\mathrm{pH}$ on the output of bicarbonate and $\mathrm{Pg}$

14 Isenberg JI, Hogan DL, Koss MA, Selling JA. Human duodenal mucosal bicarbonate secretion. Evidence for basal secretion and stimulation by hydrochloric acid and a synthetic prostaglandin $\mathrm{E}_{1}$ analogue. Gastroenterology 1986 ; 91: $370-8$.

15 Sonnenberg A, Steinkamp U, Weise A, Berges W, Weinbeck M, Rohner HG, Peter P. Salivary secretion in reflux esophagitis. Gastroenterology 1982; 83: 889-95. 